Gut, 1987, 28, S1, 109-115

\title{
Inhibition of intestinal cell proliferation by villous cell extract
}

\author{
P RAMPAL, J L NANO, AND C ZUNINO \\ From the Laboratoire d'Hépato-Gastro-Entérologie Faculté de Médecine, Nice, France
}

SUMMARY In order to verify the hypothesis that intestinal cell proliferation is controlled by a mitotic inhibitor, extracts of villous epithelial cells from different species were analysed to study their effect on the proliferation of various intestinal cells. Villous extracts from rat and rabbit strongly and reversibly inhibited cell division and DNA synthesis in a rat intestinal epithelial cell line and a primary culture of rabbit intestinal epithelial cells. This non-cytotoxic, tissue specific but not species specific factor is present in both villous cells and crypt cells, with the highest concentrations occurring in the superficial epithelial cells. Assay of a partial purification of this factor showed that it has a molecular weight of approximately 190000 daltons.

The mechanism controlling cellular proliferation in the small intestine has not yet been completely elucidated. The intestinal growth which occurs in man after intestinal damage, temporary ischaemia, ${ }^{1}$ irradiation, ${ }^{2}$ or in coeliac disease, termed type II intestinal growth response by Dowling, ${ }^{3}$ suggests that the functional zone of the intestine, the villi, controls the proliferative zone, the crypts. Furthermore, several experimental studies ${ }^{4-9}$ support the hypothesis that the digestive epithelium, like the liver, kidney, and haematopoietic tissue ${ }^{10}$ may synthesise a substance capable of interrupting cell proliferation during mitosis. Until now, however, studies aimed at showing the existence of such an inhibitor in the small intestine have been relatively uncontrolled. In many investigations, no attempt was made to show reversibility of action or absence of cytotoxicity. In several studies, the exact origin of cells providing the extract (crypt, villi, or epithelium) was not specified, and some authors have even used whole intestinal extracts. ${ }^{5-8}$ The best study to date was carried out on an intestinal epithelial cell line, ${ }^{9}$ but no data were provided concerning the effect of crypt cells on cell proliferation. Moreover, characterisation of the substance was incomplete, and species specificity was not discussed.

In our laboratory, the recent establishment of an intestinal cell line from rat fetus (IRD 98), whose characteristics readily prove its intestinal origin, ${ }^{11-12}$ provided us with the opportunity to study the control of intestinal epithelial cell proliferation.

Address for correspondence: P Rampal MD, Faculté de Médecine, 06034 Nice Cedex, France.

\section{Methods}

ANIMALS AND RELATED TECHNIQUES

Male Sprague-Dawley rats weighing 300-320 g were obtained from IFA CREDO (France). Male New Zealand albino rabbits weighing $2-2.5 \mathrm{~kg}$ from special breeding processes were also used. Culture products including medium, antibiotics and serum were purchased from GIBCO (Scotland). ${ }^{3} \mathrm{H}$ thymidine $(44 \mathrm{Ci} / \mathrm{mmol})$ and ${ }^{14} \mathrm{C}$ leucine $(50 \mathrm{Ci} / \mathrm{mmol})$ were obtained from the Commissariat à L'Energie Atomique (France). All other chemicals were obtained from commercial sources and were of the highest available purity. Several established cell lines, including rabbit kidney (RK 13), brain tumour (HeLa), dog kidney (MDCK), monkey kidney (BSC IL2), and mice embryo (FR3T3L1) were kindly provided by Dr Lefebvre (UER de Médecine, Nice, France); a human colon cancer cell line (HT 29) was provided by Dr J Marvaldi (Institut de Chimie Biologique, Marseille, France). A primary culture of rabbit epithelial intestinal cells (RIC) was isolated using the same method as for IRD-98. Alkaline phosphatase (EC3 1.3.1.) activity was assayed as described by Louvard et al. ${ }^{13}$

CELL CULTURE

Cells were grown at $37^{\circ} \mathrm{C}$ in a humidified $5 \% \mathrm{CO}_{2}$ atmosphere in the presence of Dulbecco's modified Eagle's medium supplemented with $10 \%$ fetal calf serum, penicillin $(50 \mathrm{U} / \mathrm{ml})$ and streptomycin $(50 \mu \mathrm{g} /$ $\mathrm{ml})$. The media were changed three times weekly. Cells were plated at $4.5 \times 10^{3}$ cells per $\mathrm{cm}^{2}$ in $60 \mathrm{~mm}$ 
plastic Petri dishes (Corning) for growth curve studies and in $35 \mathrm{~mm}$ dishes for ${ }^{3} \mathrm{H}$ thymidine and ${ }^{14} \mathrm{C}$ leucine incorporation. Cell counts were performed with a Coulter counter.

\section{PREPARATION OF CELL EXTRACT}

Male Sprague-Dawley rats were killed by ether inhalation, and male New Zealand albino rabbits by cervical dislocation. The entire small intestine was quickly removed and washed thoroughly with cold saline containing $1 \mathrm{mM}$ DTT. Cells were then collected by the Weiser method ${ }^{14}$ and alkaline phosphatase activity was assayed for each fraction. Fractions 1 to 4 were considered to be villous cells and 7 to 10 , crypt cells; fractions from each animal were pooled and homogenised in cold, deionised water (30 strokes of a Potter homogeniser and ultrasonication). Homogenates from 10 rats or two rabbits were combined and centrifuged at $900 \mathrm{~g}$ for 30 minutes at $4{ }^{\circ} \mathrm{C}$. The supernatant was ultracentrifuged at $105000 \mathrm{~g}$ for 60 minutes at $4^{\circ} \mathrm{C}$. An aliquot of the supernatant from the villous and crypt cell extract was sterilised by passage through $0.22 \mu \mathrm{m}$ Millex filters (Millipore) before biological assay. The high speed supernatant was then saturated to $40 \%$ by addition of solid ammonium sulphate, and stirred overnight at $4{ }^{\circ} \mathrm{C}$. The suspension was spun at 40000 $g$ for 30 minutes at $4^{\circ} \mathrm{C}$ and the pellet discarded. Crystalline ammonium sulphate was then added slowly to the supernatant to yield an $80 \%$ saturation, and stirred overnight at $4{ }^{\circ} \mathrm{C}$. The $80 \%$ saturated suspension was spun at $40000 \mathrm{~g}$ as described above, and the supernatant was discarded. The pellet (40-80\% fraction) was dissolved in a small volume of PBS, then dialysed extensively against $10 \mathrm{mM} \mathrm{NaCl}$ $10 \mathrm{mM} \mathrm{K} \mathrm{HPO}_{4}$ at $\mathrm{pH} 7.4$ (starting buffer). The $40-80 \%$ fraction was then applied to a $1.6 \times 40 \mathrm{~cm}$ column of DEAE Sephacel (Pharmacia). After sample application, the column was washed with bed volumes of starting buffer; the material retained on the column was then eluted with a linear, $0-1 \mathrm{M} \mathrm{NaCl}$ gradient in the same buffer. Protein elution was monitored by ultraviolet spectroscopy (Varian) at $280 \mathrm{~nm}$. The $1 \mathrm{M} \mathrm{NaCl}$ peak was then concentrated in B15 Minicon Concentrators (Amicon). This concentrated fraction was then extensively dialysed against PBS and sterilized by passage through $0.22 \mu \mathrm{m}$ Millex filters before biological assay. An aliquot of this fraction was applied to a $30 \mathrm{~cm} \times 7.5$ mm TSK G 3000 SW HPLC column (Kontron) and eluted with PBS $(1 \mathrm{ml} / \mathrm{min})$; protein elution was monitored by UV spectroscopy (Kontron) and each peak was collected (Gilson). Each fraction was concentrated and sterilised, as described above, before biological assay.
ASSAY OF ${ }^{3}$ H THYMIDINE INCORPORATION INTO DNA OF CELLS

The cell medium was replaced with fresh medium (1 ml) containing PBS (control) or various protein fraction concentrations $(100-400 \mu \mathrm{g} / \mathrm{ml})$ for various periods of time (three to $72 \mathrm{~h}$ ). One hour before the end of each period, $1 \mu \mathrm{Ci}$ of ${ }^{3} \mathrm{H}$ thymidine was added. The cell monolayers were then washed twice with cold PBS, treated with $5 \%$ TCA $\left(10 \mathrm{~min}\right.$ at $\left.4{ }^{\circ} \mathrm{C}\right)$ and washed three times with alcohol. The cell layer of each dish was dissolved in $0.5 \mathrm{ml}$ of $0.1 \mathrm{~N} \mathrm{NaOH}$; aliquots of this solution were used to assess the radioactivity incorporated into TCA-precipitable material by scintillation counting (Intertechnique SL 2000), and to assay cellular protein by the method of Lowry et al, ${ }^{15}$ using bovine serum albumin as the standard. Absolute amounts of incorporated radioactivity were expressed as counts per minute per microgram of cellular protein.

\section{ASSAY OF ${ }^{14} \mathrm{C}$-LEUCINE INCORPORATION INTO} CELL PROTEIN

Cells were preincubated for seven hours with medium containing either a maximally effective concentration of villous or crypt cell extract, or PBS (control). The cells were then incubated for one hour in fresh medium containing extract and ${ }^{14} \mathrm{C}$-leucine $(0.5 \mu \mathrm{Ci} /$ $\mathrm{ml})$. Thereafter, the cell monolayers were treated as described above for ${ }^{3} \mathrm{H}$ thymidine incorporation.

\section{Results}

EFFECT OF VILLOUS AND CRYPT CELL EXTRACT FROM RAT INTESTINE ON THE GROWTH OF IRD-98 CELLS

Figure 1 shows the effect of increasing quantities of villous and crypt cell extract from rat intestine on the proliferation of IRD-98 cells after $\mathbf{7 2}$ hours of culture. Maximal inhibition was obtained with $400 \mu \mathrm{g} / \mathrm{ml}$ concentrations of both villous and crypt cell extract, although the latter extract had a lesser effect. This phenomenon was confirmed by observing the action of the maximally effective extract dose $(400 \mu \mathrm{g} / \mathrm{ml})$ on IRD-98 cell growth over eight days (Fig. 2). Proliferation at day 8 was decreased by $42 \%$ for the villous extract and by $33 \%$ for the crypt extract relative to the control culture.

\section{EFFECT OF VILLOUS AND CRYPT CELL EXTRACT FROM RAT INTESTINE ON \\ ${ }^{3}$ H-THYMIDINE INCORPORATION INTO DNA OF IRD-98 CELLS}

As shown in Figure 3, DNA synthesis in IRD-98 cells after incorporation of ${ }^{3} \mathrm{H}$-thymidine was inhibited 


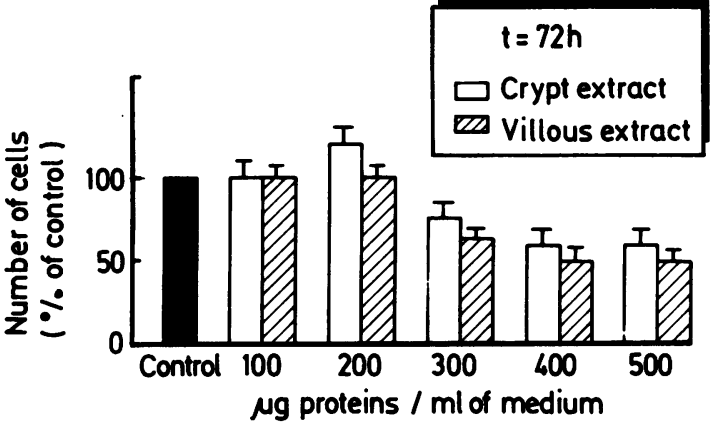

Fig. 1 Effect of various cell extract concentrations on the growth of an intestinal epithelial cell line, IRD-98. Cells were seeded at time 0 in Petri dishes (60 mm dia.) in standard medium in the absence (black column) or presence of the indicated concentrations of crypt (white columns) or villous extracts (hatched columns). The medium was changed every 24 hours. At 72 hours, cell numbers were determined in triplicate cultures from each group. Results represent the mean cell number; $S E$ was less than $10 \%$ of the mean.

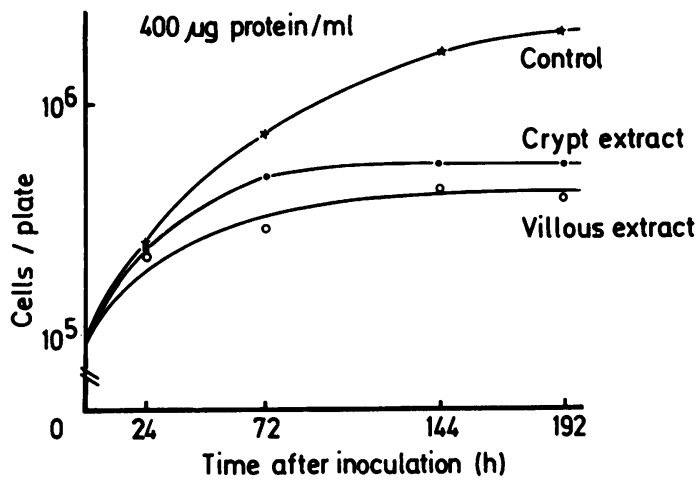

Fig. 2 Effect of intestinal cell extracts on the growth curve of the intestinal cell line, IRD-98. Cells were seeded at time 0 in Petri dishes (60 mm dia.) in standard medium in the absence $\left({ }^{*}{ }^{*}\right.$ ) or presence of $400 \mu \mathrm{g}$ protein $/ \mathrm{ml}$ of villous (O - O) or crypt (O - ) extracts. The medium was changed every 48 hours. At the times indicated, cell numbers were determined in triplicate cultures from each group. Symbols represent the mean cell number; $S E$ was less than $10 \%$ of the mean.

after eight hours by the presence of villous or crypt cell extract. This inhibition was dose dependent, the maximum inhibition of $90 \%$ being obtained with $400 \mu \mathrm{g} / \mathrm{ml}$ of villous protein. An activating effect was observed, however, with $100 \mu \mathrm{g} / \mathrm{ml}$ of protein.

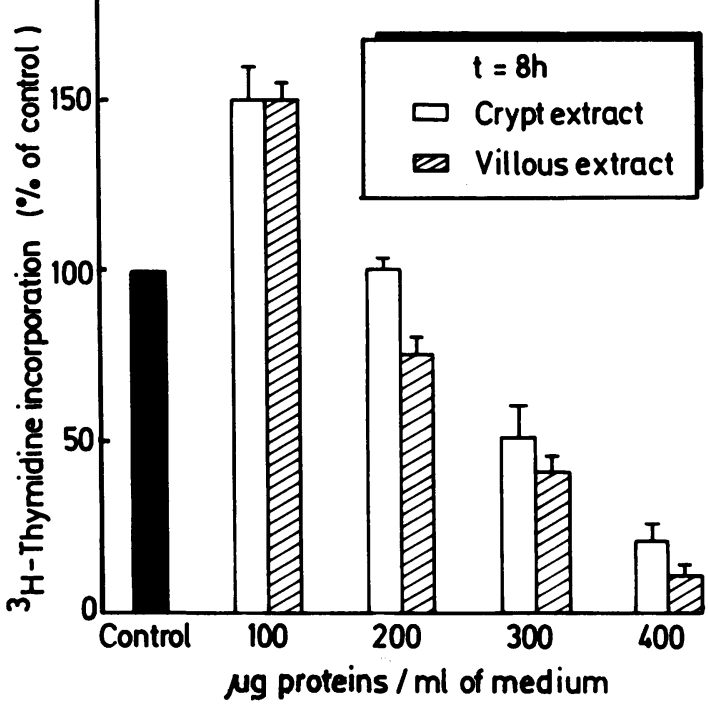

Fig. 3 Effect of various cell extract concentrations on ${ }^{3} \mathrm{H}$-thymidine incorporation into IRD-98 cells. Cells were preincubated for $8 \mathrm{~h}$ with medium containing the indicated concentration of crypt extract (white columns) or villous extract (hatched columns) and incorporation of ${ }^{3} \mathrm{H}$-thymidine $(0.5 \mu \mathrm{Ci} / \mathrm{ml})$ into $\mathrm{DNA}$ was determined. Control cells (black column) were preincubated with medium containing an equal volume of PBS. Results are the means of duplicate determinations; $S E$ was less than $10 \%$ of the mean.

KINETICS OF INHIBITION OF ${ }^{3} \mathrm{H}$-THYMIDINE INCORPORATION INTO IRD-98 CELLS BY VILLOUS AND CRYPT CELL EXTRACT FROM RAT INTESTINE

Figure 4 reveals that DNA synthesis was rapidly inhibited: after one hour of incubation with $400 \mu \mathrm{g} / \mathrm{ml}$ of villous cell extract, DNA synthesis was $50 \%$ lower than in the control culture. Maximum inhibition $(95 \%)$ was reached at 12 hours; inhibition then decreased gradually, dropping to zero after $\mathbf{4 8}$ hours. When extract was then added, inhibition again occurred. In contrast, replacement with fresh medium (Fig. 5) resulted in complete return to normal.

\section{TOXICITY}

As shown in Figure 6, preincubation of growing IRD-98 cells with rat villous and crypt cell extracts produced the expected drop in ${ }^{3} \mathrm{H}$ thymidine incorporation $(90 \%$ reduction for rat villous extract, $80 \%$ for rat crypt extract, compared with control), but had a negligible effect on ${ }^{14} \mathrm{C}$ leucine incorporation into protein $(20 \%$ reduction compared with control for villous extract, $0 \%$ for crypt extract). Viability, as 


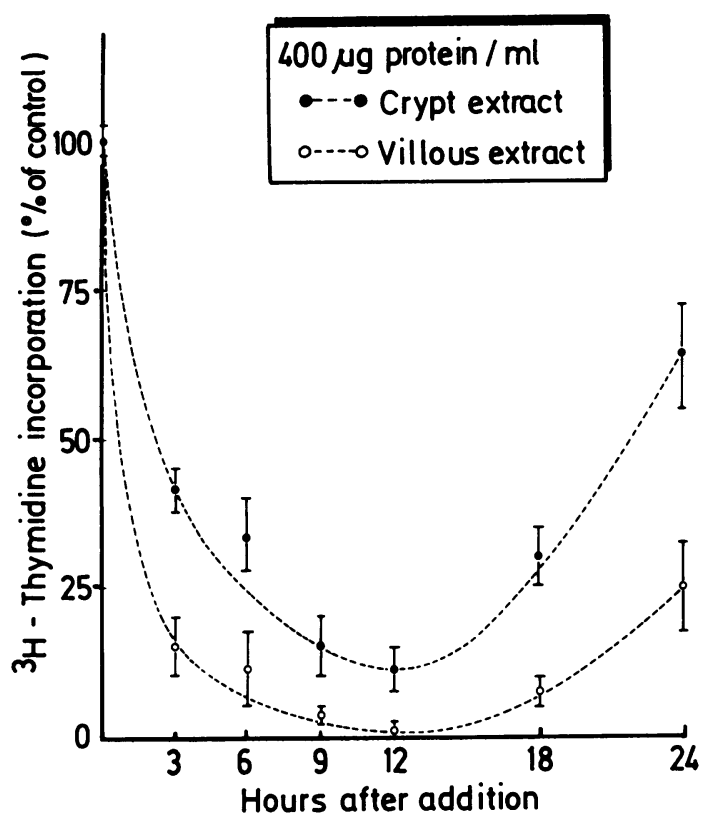

Fig. 4 Kinetics of intestinal cell extract-mediated inhibition of ${ }^{3} \mathrm{H}$-thymidine $(0.5 \mu \mathrm{Ci} / \mathrm{ml})$ incorporation into IRD-98 cells. Cells were preincubated with $400 \mu \mathrm{g}$ protein $/ \mathrm{ml}$ of crypt ( - - ) or villous extracts $(\mathrm{O}-\mathrm{O})$ for periods of time shown on the abscissa, and ${ }^{3} \mathrm{H}$-thymidine incorporation over a $1 \mathrm{~h}$ period was determined. Results are the means of duplicate determinations; $S E$ was less than $10 \%$ of the mean. Control cells were preincubated with medium containing an equal volume of PBS. Results are expressed as percent of control (PBS) incorporation.

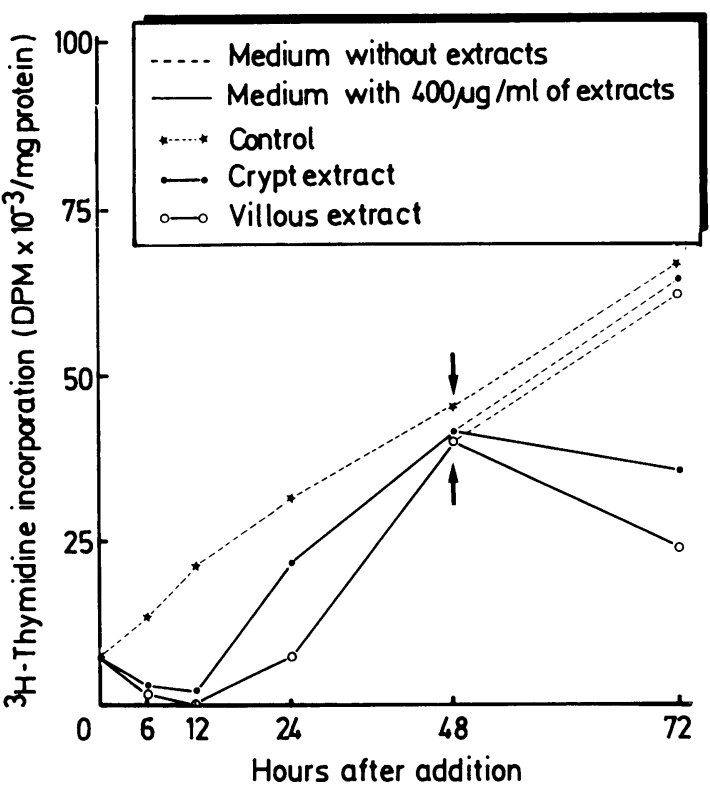

Fig. 5 Kinetics of intestinal cell extract-mediated inhibition of ${ }^{3} \mathrm{H}$-thymidine $(0.5 \mu \mathrm{Ci} / \mathrm{ml})$ incorporation into IRD-98 cells. Cells were preincubated with $400 \mu \mathrm{g}$ protein $/ \mathrm{ml}$ of crypt (O - or villous extracts $(\mathrm{O}-\mathrm{O})$ for the periods of time shown on the abscissa, and ${ }^{3} \mathrm{H}$-thymidine incorporation over a $1 \mathrm{~h}$ period was determined. Results are the means of duplicate determinations; $S E$ was less than $10 \%$ of the mean. Control cells (* .-. *) were preincubated with medium containing an equal volume of PBS. At $48 \mathrm{hr}$ (arrows), the medium was replaced with medium containing PBS (-----) or $400 \mu \mathrm{g}$ protein $/ \mathrm{ml}$ of fresh extract (-).

Table 1 Effect of rat and rabbit villous cell extracts on proliferation of several cell lines.

\begin{tabular}{|c|c|c|c|c|c|c|c|c|}
\hline \multicolumn{9}{|c|}{ Inhibition ( $\%$ of control) } \\
\hline Cell lines & $R K 13$ & Hela & $M D C K$ & $B S C 1 L 2$ & $F R 3 T 3 L$ & $H T 29$ & $R I C$ & IRD98 \\
\hline \multicolumn{9}{|c|}{$\begin{array}{l}\text { Villous } \\
\text { extract from }\end{array}$} \\
\hline Rat & 5 & 10 & 12 & 8 & 11 & 8 & 74 & 80 \\
\hline Rabbit & 9 & 14 & 6 & 5 & 2 & 2 & 78 & 70 \\
\hline
\end{tabular}

Cells were preincubated for eight hours with medium containing $400 \mu \mathrm{g} \mathrm{prot} / \mathrm{ml}$ of villous extract, and incorporation of ${ }^{3} \mathrm{H}$-thymidine $(0.5 \mu \mathrm{Ci} / \mathrm{ml})$ into DNA was determined. Control cells were preincubated with medium containing an equal volume of PBS. Results are expressed as the per cent of control incorporation and are means of duplicate determinations; SE was less than $10 \%$ of the mean.

judged by trypan blue exclusion, was estimated to be $90 \%$ during culture with extracts.

\section{SPECIFICITY}

Tissue specificity

The effect of rat villous extract was tested by evaluating thymidine incorporation in several established cell lines. Rat villous extract had no effect on
RK13, HeLa, MDCK, BSC1L2, FR3T3L1 or HT29 cells. Under the same experimental conditions, this extract was also tested on a primary culture of rabbit intestinal cells (RIC) isolated under the same technical conditions as IRD-98. The inhibition of DNA synthesis in this model $(74 \%)$ was similar to that observed for IRD-98 $(80 \%$ (Table 1$)$.

A small intestine villous cell extract was prepared 


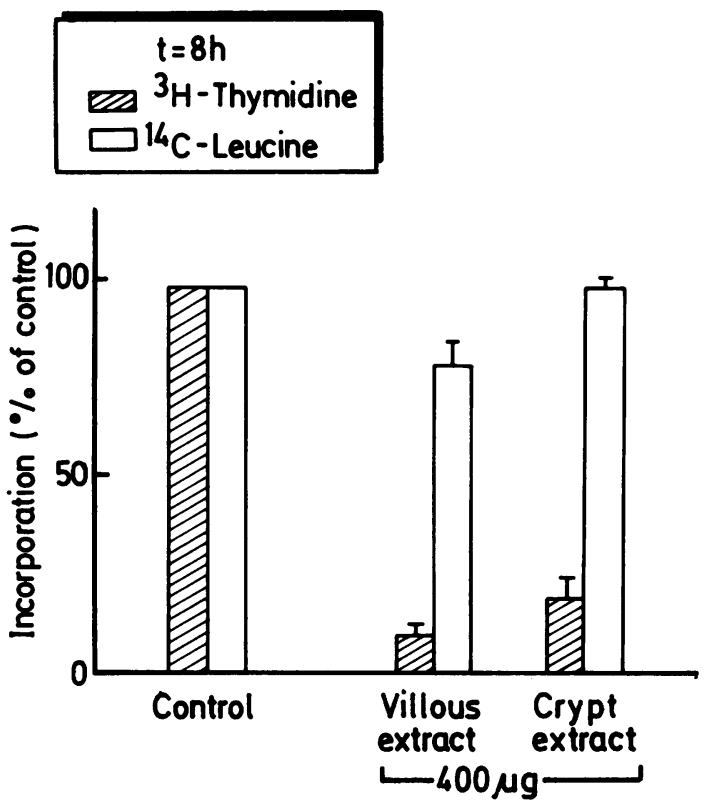

Fig. 6 Effect of intestinal cell extracts on ${ }^{3} \mathrm{H}$-thymidine and ${ }^{14} C$-leucine incorporation into IRD-98 cells. Cells were preincubated for $8 \mathrm{~h}$ with medium containing $400 \mu \mathrm{g}$ protein/ml of crypt or villous extracts, and incorporation of ${ }^{3} \mathrm{H}$-thymidine $(0.5 \mu \mathrm{Ci} / \mathrm{ml})$ into $\mathrm{DNA}$ (hatched columns) and ${ }^{14} \mathrm{C}$-leucine $(0.25 \mu \mathrm{Ci} / \mathrm{ml})$ into protein (white columns) was determined. Control cells were preincubated with medium containing an equal volume of PBS. Results are the means of duplicate determinations; $S E$ was less than $10 \%$ of the mean.

from rabbits, in the same manner as the rat extract, and was tested on the same cell lines. A similar decrease in ${ }^{3} \mathrm{H}$-thymidine incorporation (about $75 \%$ ) was observed for IRD-98 and RIC. No inhibitory action was noted for RK13, HeLa, MDCK, BSC1L2, FR3T3L1 or HT29.

\section{Organ specificity}

The effect of extracts from various organs (liver, kidney, heart, lung), prepared under the same conditions, were tested on our two cell models; no significant inhibition was observed.

\section{ATTEMPT TO PURIFY RAT VILLOUS CELL}

EXTRACT

Purification of the cytosolic villous extract from rat intestine was attempted. Essentially all of the inhibitory activity present in the high speed supernatant was recovered in the $40-80 \%$ ammonium sulphate fraction. Passage of this fraction on a DEAE column at a $\mathrm{pH}$ of 7.4 with an $\mathrm{NaCl}$ gradient from 0 to $1 \mathrm{M}$ permitted us to isolate a fraction retained on the column and eluted with $\mathrm{NaCl} 1 \mathrm{M}$ (Fig. 7). This fraction contained the inhibiting factor. After concen-

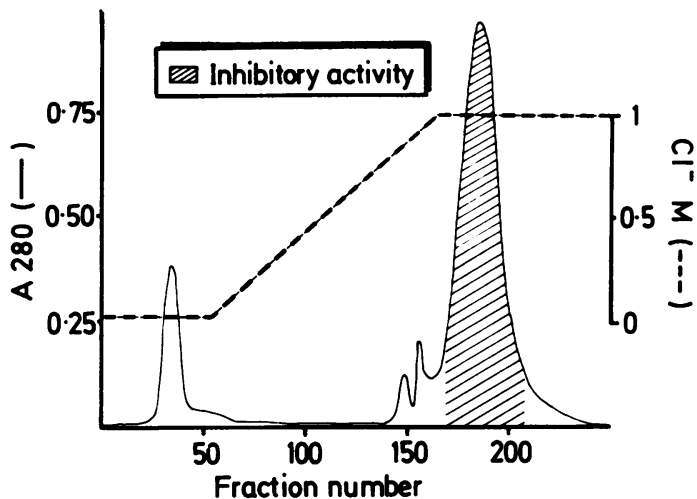

Fig. 7 Chromatography of the growth inhibitory activity derived from the 40-80\% ammonium sulphate precipitate on a column of DEA-Sephacel eluted at pH 7.4 with $\mathrm{NaCl}$ gradient. Hatched area $=$ fractions containing proliferation inhibition activity.

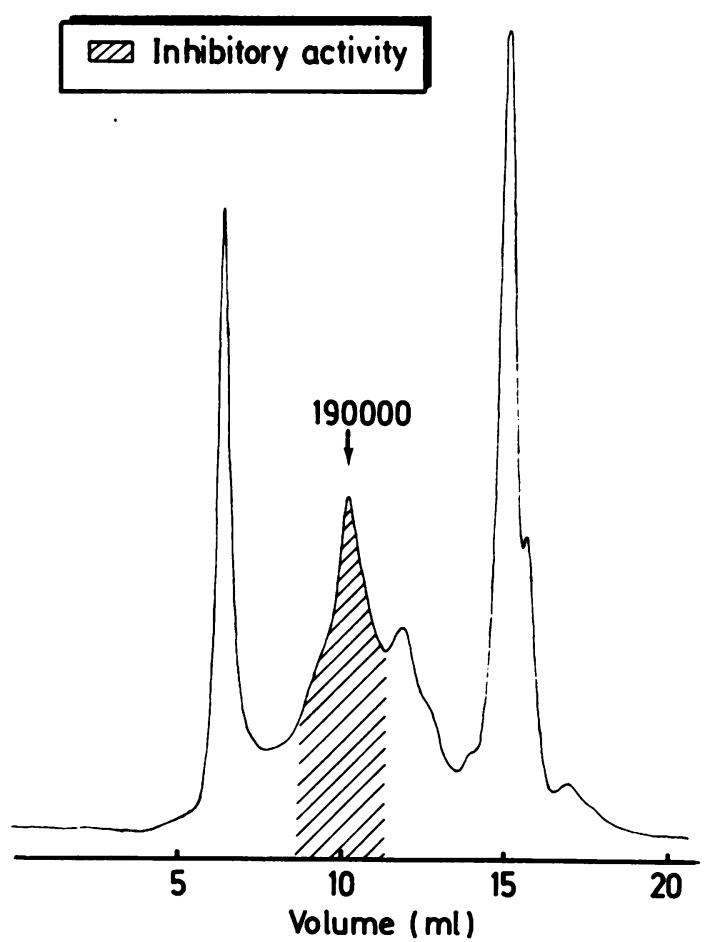

Fig. 8 HPLC of the inhibitory fraction on a TSK-3000 column. Mobile phase: $P B S \mathrm{pH} 7 \cdot 4$. Flow rate: $1 \mathrm{ml} / \mathrm{min}$. Hatched area: significant inhibitory activity.

tration and dialysis, the fraction was applied on a TSK 3000 HPLC column (Fig. 8). Elution isolated four peaks with molecular weights of 450000,190000 , 120000 , and 45000 daltons. The inhibitory effect corresponded to the second peak, which had a 
Table 2 Effect of cytosolic extracts from various organs on the proliferation of rat and rabbit epithelial intestinal cells.

Inhibition (\% of control)

\begin{tabular}{lccccc}
\hline Extract from: & Liver & Kidney & Heart & Lung & Intestine \\
\hline Cell lines & & & & & \\
IRD 98 & 22 & 5 & 1 & 13 & 70 \\
RIC & 10 & 2 & 3 & 11 & 78 \\
\hline
\end{tabular}

Cells were preincubated for eight hours with medium containing $400 \mu \mathrm{g} \mathrm{prot} / \mathrm{ml}$ of cytosolic extract from various organs and incorporation of ${ }^{3} \mathrm{H}$-thymidine $(0.5 \mu \mathrm{Ci} / \mathrm{ml})$ into DNA was determined. Control cells were preincubated with medium containing an equal volume of PBS. Results are expressed as the per cent of control incorporation and are means of duplicate determinations; SE was less than $10 \%$ of the mean.

molecular weight of 190000 . The ED50, determined by ${ }^{3} \mathrm{H}$-thymidine incorporation, was around $250 \mu \mathrm{g} /$ $\mathrm{ml}$ with the crude extract versus $65 \mu \mathrm{g} / \mathrm{ml}$ with the purified factor. The purified fraction had the same properties as those described previously for the crude extract.

\section{Discussion}

Regulation of cell proliferation by negative feedback, mediated by endogenous mitotic inhibitors referred to as chalones, has been suggested for a variety of tissues. ${ }^{16}$ The demonstration of inhibitory activity in relevant tissue extracts has indicated that the gastrointestinal tract might also be controlled in this way..$^{4-917}$ The present study supports this concept by revealing that intestinal villous cells contain a factor which specifically inhibits the proliferation of intestinal epithelial cells in culture. This factor is also present in crypt cells because up to $80 \%$ inhibition of DNA synthesis was observed after eight hours of incubation in the presence of crypt extract. In the presence of villous extract, inhibition reached $90 \%$ under the same experimental conditions. It is unlikely that the crypt cells were contaminated by villous cells because histological control of the Weiser technique (data not shown) showed satisfactory separation of villous cells from crypt cells. Unlike alkaline phosphatase, which is found in high concentrations only in the top half of the villi, our factor might have a distribution analogous to that of sucrase and maltase, which are present in non-negligible amounts in crypt cells. ${ }^{18}$

The factor we have isolated does not seem to be cytotoxic, as staining with trypan blue revealed conservation of cellular viability. Moreover, the action of this inhibitor is reversible; protein synthesis tested by incorporation of ${ }^{14} \mathrm{C}$-leucine was not modified during incubation in the presence of the factor.

This factor seems to be tissue specific; it inhibited proliferation of two intestinal epithelial cell cultures (the IRD-98 line originating in rat fetus small intestine and a primary culture of adult rabbit small intestine) but had no effect on tissue of extradigestive origin or on tissue from digestive tract tumours. No inhibitory activity was observed when cytosolic extracts of various other digestive and extradigestive tissues were tested on intestinal cell lines IRD-98 and RIC. By contrast, this factor does not seem to be speciesspecific: whether isolated from rat or rabbit intestine, it had a comparable effect on the proliferation of intestinal epithelial cells from either of these two species. It therefore satisfies the criteria for a chalone established by Bullough and described in several monographs. ${ }^{1019} 20$

Purification of this factor from cytosolic villous cell extract showed that it was a negatively charged substance because it was retained to a great degree on DEAE. Its apparent molecular weight, as measured by gel filtration, is approximately 190000 . It has numerous similarities with the substance isolated by May et al, ${ }^{10}$ which inhibits proliferation of IEC-6 cells. ${ }^{21}$ Whether this factor is related to this diamineoxidase/ornithine-decarboxylase system has not been established. ${ }^{22}$ Diamine-oxidase is extremely active in mature villous tip cells, and might be a negative feedback inhibitor of crypt cell proliferation, but existing data are insufficient to permit firm conclusions on this point.

The identification of an endogenous inhibitor in this study supports the hypothesis of intrinsic control of crypt cell proliferation in the small intestine by a negative feedback mechanism. Rigorous purification and characterisation of this factor should provide better insight into the molecular basis of intestinal adaptation.

The authors are very grateful to Ms DCzerurka for expert technical assistance, Ms M P Mayer for skillful typing, and Ms N Rameau for careful reading of the manuscript. This work was supported by grants from the Association pour la Recherche sur le Cancer (no. 6577), the Comité Doyen Jean Lépine, the Conseil Général des Alpes Maritimes and the UER de Médecine de Nice.

\section{References}

1 Rijke RPC, Hanson, WR, Plaisier HM. The effect of ischemic villus damage on crypt cell proliferation in the small intestine: evidence for a feedback control mechanism. Gastroenterology 1976; 71: 786-92.

2 Rijke RPC, Plaisier H, Hoogeveen AT. The effect of continuous irradiation on cell proliferation and matura- 
tion in small intestinal epithelium. Cell Tissue Kinet $1975 ; 8$ : 441-53.

3 Dowling RH. Small bowel adaptation and its regulation. Scand J Gastroenterol 1982; 17: suppl 74: 54-74.

4 Tutton PJM. Control of epithelial cell proliferation in the small intestinal crypt. Cell Tissue Kinet 1973; 6: 211-16.

5 Brugal G, Pelmont J. Existence of two chalone-like substances in intestinal extract from the adult newt inhibiting embryonic intestinal cell proliferation. Cell Tissue Kinet 1975; 8: 171-87.

6 Sassier P, Bergeron M. Specific inhibition of cell proliferation in the mouse intestine by an aqueous extract of rabbit small intestine. Cell Tissue Kinet 1977; 10: 223-31.

7 Sassier P, Bergeron M. Specific inhibition of cell proliferation in the mouse intestine by an aqueous extract of rabbit colon. Cell Tissue Kinet 1978; 11: 641-50.

8 Sassier P, Bergeron M. Existence of an endogenous inhibitor of DNA synthesis in rabbit small intestine specifically effective on cell proliferation in adult mouse intestine. Cell Tissue Kinet 1980; 13: 251-61.

9 May RJ, Quaroni A, Kirsch K, Isselbacher K. A villous cell-derived inhibitor of intestinal cell proliferation. $\mathrm{Am}$ J Physiol 1981; 241 : G520-7.

10 Houck JC. Chalones. Amsterdam, Oxford: North Holland Publishing Company, 1976.

11 Negrel R, Rampal P, Nano JL, Cavenel C, Ailhaud G. Establishment and characterization of an epithelial intestinal cell line from rat fetus. Exp Cell Res 1983; 143: 427-37.

12 Nano JL, Barbaras R, Negrel R, Rampal P. Regulation of cholesterol synthesis and binding of lipoproteins in cultured rat intestinal epithelial cells. Biochim Biophys Acta 1986; 876: 72-9.
13 Louvard D, Maroux S, Baratti J, Desneulle P, Mutaftschiev S. On the preparation and some properties of closed membrane vesicles from hog duodenal and jejunal brush border. Biochim Biophys Acta 1973; 291: 74763.

14 Weiser MM. Intestinal epithelial cell surface membrane glycoprotein synthesis I. An indicator of cellular differentiation. J Biol Chem 1973; 248: 2536-41.

15 Lowry OH, Rosebrough NJ, Farr AL, Randall RJ. Protein measurement with the Folin phenol reagent. $J$ Biol Chem 1951; 193: 265-75.

16 Bullough WS. Chalone control mechanisms. Life Sci 1975; 16: 323-8.

17 Philpott GW. Tissue specific inhibition of cell proliferation in embryonic stomach epithelium in vitro. Gastroenterology 1971; 61 : 25-34.

18 Simon PM, Kedinger M, Raul F, Grenier JF, Haffen K. Developmental pattern of rat intestinal brush-border enzymic proteins along the villus-crypt axis. Biochem $J$ 1979; 178: 407-13.

19 Forscher BK, Houck JC. eds. Chalones Proc. First Sym International Chalone Conf. Concept and current researches. Nat Cancer Inst Monogr. 1973; 38.

20 Houck JC, Hennings $H$. Chalones. Specific endogenous mitotic inhibitors. FEBS Lett 1973; 32: 1-8.

21 Quaroni A, Wands J, Trelstad RL, Isselbacher KJ. Epitheloid cell cultures from rat small intestine. Characterization by morphologic and immunologic criteria. $J$ Cell Biol 1979; 80: 248-65.

22 Luk GD, Baylin SB. Ornithine decarboxylase in intestinal maturation, recovery and adaptation. In: Robinson JWL, Dowling RH, Riecken EO eds. Mechanisms of intestinal adaptation. Lancaster: MTP Pres, 1981: $65-80$. 